Mavi Atlas, 9(1)2021: 77-86

Araştırma Makalesi | Research Article

Makale Geliş | Received: 14.01.2021

Makale Kabul | Accepted: 16.02.2021

DOI: 10.18795/gumusmaviatlas.860971

Eda TOK

Dr. Öğr. Üyesi.|Assist.Prof.Dr.

Düzce Üniversitesi, Fen Edebiyat Fakültesi, Türk Dili ve Edebiyatı Bölümü, Düzce-TÜRKIYYE

Düzce University, Faculty of Arts and Sciences, Department of Turkish Language and Literature, Düzce- TURKEY

ORCID: 0000-0002-9939-0154

edatok@duzce.edu.tr

\title{
Sebk-i Hindî Tesiri Bağlamında Mahvî Dîvânı’nda Karamsarlık
}

\section{$\ddot{\mathrm{O} z}$}

Sebk-i Hindî, Fars edebiyatı ve Hint sanat zevkinin senteziyle meydana gelmiş olup klasik Türk şiirinde XVII. yüzyıl ortalarında görülmeye başlamıştır. Klasik Türk edebiyatında kendine has nitelikler de gösteren bu üslup, XVII ve XVIII. yüzylllarda Nefî, Fehîm-i Kadîm, Şehrî, İsmetî, Nailî, Nedîm-i Kadîm, Neșâtî, Râsih, Nâbî, Arpaeminizâde Sâmî, Halepli Edîb ve Şeyh Galib gibi şairler üzerinde etkili olmuştur. XVII. yüzyıl şairlerinden Mahvî Ahmed Çelebi de Sebk-i Hindî’nin tesirinde kalan ve șiirlerinde bu üslubun dil ve muhteva özelliklerini belirgin bir biçimde kullanan şairlerden biridir. Mahvî’nin hayatı hakkındaki bilgiler oldukça sınırlıdır. Kütahyalı olduğu anlaşılan şairin mesleğine dair bilgiler de mevcut değildir. Şairin bilinen tek eseri dîvânıdır. Mahvî’nin şiirlerinde, Sebk-i Hindî tesirindeki şairlerin eserlerinde çoğunlukla hâkim olan ve Sebk-i Hindî şiirinin ana temaları arasında yer alan ızdırap ve karamsarlığın yoğun bir biçimde görülmesi dikkat çekmektedir. Sebk-i Hindî̀yi benimseyen şairlerin şiirlerinde genellikle insanın dış dünyasından daha ziyade iç dünyasına yöneliş söz konusudur. Şairler, dıș dünyayı da kendi duygu ve hayallerini anlatmada kullanmıştır. Bu durum ızdırap, elem, karamsarlık gibi ruh hâllerini Sebk-i Hindî şiirinin konularından biri hâline getirmiştir. Bu çalışmada da Mahvî̀nin şiirlerinden seçilen örnek beyitlerle şairin şiirlerinde dikkat çekici boyutta yer alan karamsar ruh hâli gösterilmiştir. Mahvînin şiirlerinde talihsizliğini bildiren ifadelerin fazlalığı, şiirlerinin neredeyse tamamına hâkim olan düşkünlük ve ümitsizlik hâli, şairin olumsuzluk çağrıştıran "Mahvî” mahlasını tercih etmesi Sebk-i Hindî tesiri bağlamında değerlendirilmiştir.

Anahtar Kelimeler: Mahvî, Dîvân, Sebk-i Hindî, Karamsarlık.

\section{Pessimism in Divan of Mahvi in the Context of Influence of Sebk-i Hindi}

\begin{abstract}
Sebk-i Hindi, which came into existence by synthesis of Persian Literature and Indian aesthetic, started to appear in Classical Turkish Poetry by mid-17th-century. This style, which has its unique characteristics in Classical Turkish Literature, was influential on 17th- and 18th-century poets such as Nefî, Fehîm-i Kadîm, Șehrî, İsmetî, Nailî, Nedîm-i Kadîm, Neşâtî, Râsih, Nâbî, Arpaeminizâde Sâmî, Halepli Edîb and Şeyh Galib. 17th-century poet Mahvi Ahmed Çelebi was also one of the poets who was influenced by Sebk-i Hindi and who used stylistic and thematic elements of this style in a distinct way in their poetry. Information about the life of Mahvi is quite limited. Moreover, information regarding the profession of the poet, known to be from Kütahya, is lacking. The only known work of the poet is his Divan. In Mahvî's poetry, the agony and pessimism, which is mostly dominant in the works of the poets under the influence of Sebk-i Hindî and which is one of the main themes of Sebk-i Hindî poetry, stands out with their intense appearance. Poets who adopted Sebk-i Hindi verged towards inner world of themselves instead of outer world in their poems. Poets used outer world as a means to express their emotions and imagination. This situation made states of mind like agony, sorrow, and pessimism one of the themes of Sebk-i Hindi poetry. In this work, pessimistic state of mind which is remarkable in poems by Mahvi is shown with a selection of example couplets from poet. Excessive usage of expressions that reveal misfortune in Mahvi's poems, states of impotence and despair which dominates almost all of Mahvi's poems, and his choice of pen name, "Mahvi" that connotates negation have been evaluated in the context of influence of Sebk-i Hindi.
\end{abstract}

Keywords: Mahvi, Divan, Sebk-i Hindi, Pessimism. 


\section{Giriş}

Osmanlı İmparatorluğu'nun gerileme sürecine girdiği, siyasi ve sosyal bakımdan çeşitli olumsuzlukların yaşandığı XVII. yüzyıl kültür ve sanat bakımından oldukça verimli bir dönemdir. Klasik Türk edebiyatı bu dönemde nazım ve nesir sahasında olgunlaşma dönemine girmiş, güçlü eserler meydana getirilmiştir. Bu dönemde nazım alanında Nef'î, Şeyhülislam Bahâyî, Nâ’ilî-i Kadîm, Neşâtî, Nâbî gibi kendine has üslubu olan şairler yetişmiştir. XVII. yüzyılda dört edebî üsluptan bahsetmek mümkündür. Bu üslupları Bâkî’nin temsil ettiği şiir anlayışını devam ettiren şairler tarafindan sürdürülen Klasik Üslup, bu dönemde etkisi görülmeye başlayan yabancı üslup olmakla birlikte Türk edebiyatında kendine has nitelikler de gösteren Sebk-i Hindî, Nâbî ile özdeşleşmiş olan Hîkemî Tarz ve daha sonraki dönemlerde gelişecek Mahallîleşme üslubuna da kaynaklık etmiş olan Mahallî Tarz olarak saymak mümkündür.

\section{Sebk-i Hindî ve Karamsarlık}

Sebk, sözlükte "bir şeyi eritmek, kalıba dökmek; kalıp, tarz ve üslup" anlamlarında geçmektedir. Bir edebî terim olarak ise sebk, "ibârenin tarz ve tertibi" anlamına gelmektedir (Bilkan, 2009: 253). Sebk-i Hindî̀ ise XVII ve XVIII. yüzyıllarda klasik Fars ve Türk şiirine hâkim olan yeni üslubun adlandırılmasında kullanılmış bir terimdir. Sebk-i Hindî İran, Türk ve Hint kültürlerinin etkisiyle meydana çıkmış ortak bir zevkin ürünüdür.

Sebk-i Hindî, klasik Türk şiirinde XVII. yüzyıl ortalarında görülmeye başlamış, XVII ve XVIII. yüzyıllarda Nefî, Fehîm-i Kadîm, Şehrî, İsmetî, Nailî, Nedîm-i Kadîm, Neşâtî, Râsih, Nâbî, Arpaeminzâde Sâmî, Halepli Edîb ve Şeyh Galib gibi şairler üzerinde etkili olmuştur. Sebk-i Hindî’nin tesirinde kalan ve şiirlerinde bu üslubun özellikleri belirgin bir biçimde görülen şairlerden biri de Mahvî'dir.

Sebk-i Hindî şïrlerinde diğer üsluplar ile yazılmıss şiirlere göre daha derin ve girift bir anlam söz konusudur. $\mathrm{Bu}$ anlam derinliği ve giriftliği çoğu zaman anlaşılması zor ifadelerin ortaya çıkmasına sebep olmuştur. Bu üslubu benimseyen şairlerin şiirlerinde insanın diş dünyasından daha ziyade iç dünyasına yönelme olduğu ve dış dünyayı da kendi duygu düşünce ve hayallerini anlatmada kullandıkları görülmektedir. ${ }^{2}$ Bu durum 1zdırap, elem, karamsarlık gibi ruh hâllerini Sebk-i Hindî şiirinin konularından biri hâline getirmiştir. Bu temaların soyut olması ve insan ruhunu daha çok yansıtması, söz konusu üslubun tesirinde kalan şairler tarafindan daha çok tercih edilmelerine yol açmışır. Şiirlerde bu temaların işlenmesi, insan ruhunun derinliklerine inilmesi, muhayyilenin genişlemesi ve orijinal mazmunların ortaya çıkmasına da sebep olmuştur.

Sebk-i Hindî şairlerinin şiirlerinde özellikle gazellerde sürekli dile getirilen aşk acısı dışında ferdin başka acı ve 1zdıraplarından da söz edilmektedir. Sebk-i Hindî şairleri ferdîleşen bir şiir dili oluşturmaya çalışmış, geleneksel biz dili yerine ben dilini kullanmaya başlamıştır. Ben dili, şiirde hayattaki bazı gerçek olayların şahsî duygularla yansıtılması, ferdî açıdan değerlendirilmesi, kişisel dünyadaki acı, ızdırap ve çırpınışın anlatılması, hayattan şikâyet, karamsarlık ve bedbinlik gibi muhteva açısından bazı yenilik ve değişikliklere de sebep olmuştur (Babacan, 2012: 390-392). Sebki Hindî şairlerinin şiirlerinde divan şiirinin klasik çizgisini temsil eden şairlerinden farklı olarak

\footnotetext{
${ }^{1}$ Sebk-i Hindî ayrıntılı bilgi için bk.: Babacan, 2012; Mum, 2006; Toker, 1996.

2 "Sebk-i Hindî şairleri, etraflarında olup biten her şeye dikkatli bir gözlemci olarak bakmış ve hemen her şeyde şiire taşınmaya elverişli malzeme aramışlardır. Onlar, bir yandan önceki edebî metinleri okuyarak geleneğin sağladığı imkânları tekrar tekrar elden geçirmiş, bir yandan da hayatın bizzat kendisinden şiire malzeme taşıyarak yeni imkânlar temin etmeye çalışmışlardır. Bu bağlamda, başta tabiat olmak üzere, aile, cemiyet, devlet, ticaret, tarım, eğitim ve her çeşit meslek hayatı, şairlerin dikkat ve ilgilerini çekmeye başlamıştır. Aslında başından beri bütün bu alanlar daima şairlerin ilgisini çekmiştir. Fakat şairler, hiçbir dönemde bu alanlarla bu dönemdeki kadar fazla ilgilenmemiş, bu kadar çok malzemeyi şiire taşımamışlardır. Sebk-i Hindî’nin etkili olduğu dönemde, önceki dönemlerle karşılaştırıldığında şairlerin kendi duygu, düşünce ve hayallerini anlatmada çok daha geniş imkânlara sahip oldukları görülmektedir. Onlara bu geniş imkânları sunan, bu yeni şiir malzemesidir.” (Mum, 2011: 47).
} 
dikkati çeken aşırı bir biçimde içe kapanma, ruhsal bunalımlar ve bireyselleşme söz konusudur. $\mathrm{Bu}$ bireyselleşmede şairlerin içinde yaşadıkları dönemin olumsuz şartlarının ve Sebk-i Hindî’nin payı vardır (Demirel, 2006: 77). “Ac1, ızdırap ve çırpınışla ben diline yönelen Hint üslubu şairleri hayattan şikâyet ve artan karamsarlıkla, bedbinliğe yönelen duygulara doğru giderler. Bu durumun ortaya çıkmasında, Nâilî’nin hayatında olduğu gibi, şahsen maruz kaldıkları itilmişlik, devlet yönetiminden uzaklaşma ve fizikî rahatsızlıklar da etkili olabilir.” (Babacan, 2012: 398).

Izdırap, Hind üslubu şairlerinin belirgin bir özelliğidir. Nâilî’nin de tüm şiirlerinde işlediği bir konudur. Nâilil'nin şiirlerinde 1zdırap sadece bu üslubun bir gereği olarak değil, aynı zamanda onun hayatının bir yansıması olarak yer alır. Şairin zayıf ve hastalıklı kişiliği, meslek hayatında ilerleyememesini, hayatında çok acı çekmesi onun şiirlerinde felekten, devrinden şikâyet etmesine sebep olmuştur. Şair çektiği ızdırabı Hint üslubunun özelliğine de uyarak şiirlerinde işlemiştir. Nâilî Dîvânı acının, 1zdırabın ve umutsuzluğun dile getirildiği beyitlerle doludur (İpekten, 2016: 72-73):

Şeb-i firâkda baht-1 siyâhımızdır hep

Eden bizi eser-i subhgâhda nevmîd

(Ayrılık gecesinde bizi sabah vaktinin işaretlerinden umutsuz bırakan hep kara bahtımızdır.)

Nâ-ümîd ol haste-i cân-der-gulûyum ki kazâ

Baht-1 bîmâr1 tabîb-i çâre-sâz eyler bana

(Canı boğazında öyle ümitsiz bir hastayım ki Kazâ-yi ilâhî hasta bahtı bana derman bulucu hekim eyledi.)

Şehrî de klasik Türk edebiyatında Fuzûlî’ den sonra yetişen divan şairleri içinde 1zdırabı sıkça terennüm eden Nâilî, Fehîm ve Neşâtî gibi şairlerden biri olarak kabul edilebilir. Şehrî̀nin başta gazelleri olmak üzere, kaside ve musammatlarında bu tür bir ızdırabın havasını farklı boyutlarda hissetmek mümkündür. Şairi böylesine derin bir ızdırap havasına götüren, zamandan, felekten ve ortamdan şikâyet etmesine sebebiyet veren birçok neden bulunmaktadır. Bu nedenlerin bazıları şairin sosyal çevresinden, bazıları aile çevresinden ve bazıları da temsilcisi olmaya çalıştığı edebî üsluptan kaynaklanmaktadır. Şairin içinde yaşadığ 1 dönemde bizzat şahit olduğu, devletin ve toplumun hemen her kesiminde kendisini hissettirmeye başlayan sosyal hayattaki çözülme ve çürüme, ekonomik ve askerî alanlardaki kötü gidiş şair üzerinde etkili olmuştur. Oğlunun ölümü, evinin soyulması ve rahat ve huzur içinde bir hayat sürebileceği imkânlardan yoksun olması gibi hususlar, içinde bulunduğu sosyal çevresinden kaynaklanmıştır. Şehrî’nin kişiliğini etkileyen üçüncü ve son husus, dönemin çoğu şairi gibi Şehrî'yi de etkisi altına alan ve temel konularından biri ızdırap olan Sebk-i Hindî'dir. Bütün bu olumsuz gelişmeler veya durumlar bir araya geldiğinde ortaya pesimist bir insan ruhunu yansıtan tablo çıkmaktadır (Demirel, 2017: 6-7).

Şehrî’nin şiirleri incelendiğinde de zamandan şikâyet ettiği, ızdırabın yansıtıldığ1 çok sayıda örneğe rastlamak mümkündür:

Kadrümüz Şehrî n'ola fehm eylemezse rûzgâr

Biz gelince dehre oldı dîde-i iz ânı kûr (Demirel, 2017: 79)

(Şehrî, zaman bizim kıymetimizi bilmezse buna şaşlır mı? Biz dünyaya gelince dünyanın anlayış gözü kör oldu.)

Kısacası toplum hayatındaki bozukluk, oğlunun ölümü, evinin soyulması ve Sebk-i Hindî̀nin önemli temalarından biri olan ızdırap ve karamsarlığın bir araya gelmesi Şehrî’nin edebî kişiliğinin şekillenmesinde oldukça etkili olmuştur. Sebk-i Hindî’nin temsilcilerinden olan Nâ̂lî ve 
Şehrî’nin şiirlerinde ızdırap temasının yoğun olmasında üslubun özelliğinin yanı sıra yaşamlarının da tesiri olduğunu söylemek mümkündür.

\section{Mahvî’nin Şiirlerinde Karamsarlık}

XVII. yüzyıl şairlerinden Mahvî Ahmed Çelebi'nin hayatı hakkındaki bilgiler oldukça sinırlıdır. Kütahyalı olduğu anlaşılan şairin mesleğine dair bilgiler de mevcut değildir. Aypay'a göre Mahvî'nin geçimini kâtiplikle sağladığı ihtimali kuvvetlidir (Aypay, 1998: 227-228). Mahvî Ahmed Çelebi’nin mesleğine ilişkin bilgiler kâtiplikle geçimini sağlamış olabileceği yönündeki tahminlerden öteye gidememektedir.

Şairin ölüm tarihiyle ilgili olarak kaynaklarda iki farklı bilgi vardır. Safâyî şairin ölümünü 1089/1678-79 olarak bildirmektedir (Çapan, 2005: 477). Şeyhî, şairin 1055 yllinda vefat ettiğini bildirirken (Özcan, 1989: 177), İsmail Beliğg, "Bin elli bes senesinde mahv-i vücûd eyledi." ifadesini kullanarak şairin ölüm tarihini 1055/1645-46 olarak vermektedir (Abdulkadiroğlu, 1985: 484). Mahvînnin bilinen tek eseri dîvândır. Mahvî'nin dîvânında 2 kaside, 1 mesnevi, 1 terkîb-i bend, 1 tercî'-i bend, 129 gazel, 4 müfred bulunmaktadır (Tok, 2020).

Mahvî’nin şiirleri dil ve muhteva bakımından incelendiğinde döneminde etkili olan Sebk-i Hindî’den etkilendiği ve üslubun özelliklerini şïrlerine yansıttığını söylemek mümkündür. Aynı zamanda Mahvî̀nin şiirlerinde Örfî̀-i Şîrâzî (öl. 1591), Feyzî-i Hindî (öl.1595), Hâkânî-i Şirvânî (öl.1199), Muhteşem-i Kâşânî (öl. 1588), Selmân-1 Sâvecî (öl.1376), Kemâleddîn-i İsfahânî (öl. 1240?), Nef'̂̀'(öl. 1635) isimlerini anması onlardan etkilendiğine de işaret etmektedir. Şairin şiirlerinden hareketle çağdaşları Nâilî, Neşâtî, Fehîm-i Kadîm ve bilhassa Şehrî̀den etkilendiği de anlaşılmaktadır. Mahvî’nin dili gerek yaşadığı dönemin etkisi gerekse Sebk-i Hindî’nin tesiri altında kalmasından dolayı genel itibarıyla ağırdır. Mahvî’nin şïrlerinde özellikle soyut ve somut kelimelerin birleştirilmesiyle elde edilen, üç-dört unsurdan oluşan uzun tamlamalara sıkça tesadüf edilmektedir. Mahvînnin şiirlerinde Sebk-i Hindî’nin belirgin özelliklerinden biri olan yeni hayaller bulma, hayallere derinlik kazandırma çabasında olduğu da zaman zaman görülmektedir. Şairin şiirlerinde aşırıya kaçan mübalağa örneklerinin çokça bulunması da yine dikkat çeken özellikler arasındadır (Tok, 2020).

Sebk-i Hindî şiirinde ön plana çıkan temalardan olan ızdırap Mahvî’nin şiirlerinde de yoğun bir biçiimde görülmektedir. Şairin, şiirlerinde gam, derd, ab, dâg, nâle, mibnet, girye, nâ-ümîd̂̀, nâ-murâd,

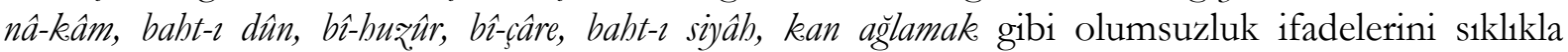
kullandığı ve ızdırabı ön planda tuttuğu görülmektedir. Bu bağlamda şairin şiirlerinden seçilen örnek beyitlerle dikkat çeken boyuttaki karamsar ruh hâli gösterilmeye çalışılacaktır.

Mahvî’nin mahlas tercihi söz konusu karamsar ruh hâli bağlamında dikkat çekicidir. Bilindiği üzere divan şairlerinin şiirlerinde kullandıkları takma adlara "mahlas" denilmektedir. Şairler, şiirlerinde esas adı yerine daha ziyade şïrlerinde kendileri tarafından seçilen veya üstatları tarafindan verilen bu mahlası kullanirlar.

Akün, mahlaslara hâkim olan zihniyet ve imajların çok daha iyi anlaşılması için mahlasları bazı kategoriler içinde değerlendirir. Bunlar:

Psikolojik bir tutum ve vasfi aksettirenler hemen dikkati çeker: Fevrî, Huzûrî, Hürremî, Gamî, Neşâtî, Mâtemî, Sürûrî, Figânî, Şevkî, Hüznî, Safâyî, Nâlişî, Sükûnî, Zârî...

Kazanılmış bir meziyeti, itiyat hâline gelmiş bir davranışı bildirenler en sevilmiş, en tercih edilmiş mahlaslardandır: Azmî, Cezmî, Merâmî, Murâdî, Bezmî, Mahremî, Refîkî, Hemdemî, Ülfetî, Ünsî, Niyâzî, Edâyî, Duâyî, Hamdî, Şükrî, Rızâi, Sâcidî, Zikrî, Sücûdî, Abdî, Mutîi, Kabûlî, Rağbetî, Gayretî, Va‘dî, Ümîdî...

Bir grup mahlasta ise üstünlük iddiası vardır: Ulvî, İzzetî, Bülendî, Re’fetî, Rif́atî, Refî̀, Kebîrî, Hâkānî, Hüsrevî, Ferîdî, Arşî, Evcî... 
Bir kısım şair de kendilerine cennete liyakat, ilâhî makama yakınlık nisbet eden mahlaslara yönelmiştir: Adnî, Firdevsî, Bihiştî, Huldî, Kevserî, Riyâzî, Hüdâyî, İlâhî, Ledünnî, Kurbî, Yakînî..

Bazı şairler tabiattan alınma şairane mahlaslar taşımak isterler: Bahrî, Mevcî, Âbî, Revânî, Gülâbî, Deştî, Fezâyî, Âfitâbî, Şemsî, Mihrî, Hâverî, Necmî, Ahterî, Hilâlî, Bedrî, Âteşî, Berkî, Ra dî̀, Nehârî, Şâmî, Bahârî, Hazânî, Nesîmî, Sabâyî, Andelîbî, Kebûterî, Nebâtî, Nergisî...

Öte yandan mahviyet, kendini hor görme, bir düşkünlük hâli, bir hayat ârızası veya talihsizlik bildiren mahlaslara da talip olunmuştur: Gubârî, Türâbî, Hâkî, Zaîfî, Za'fî, Sâilî, Fakîrî, Gedâyî, Garîbî, Cüdâyî, Firâkî, Hicrî, Esîrî, Nahîfî, Nizârî, Aczî, Mahvî, Helâkî, Cevrî, Cefâyî, Fânî, Fenâî, Günâhî, Özrî...

Bazı mahlaslar ise bir kavram etrafinda bir daire halinde toplanır: Bedî̀, Beyânî, Fasîhî, Fehmî, Fikrî, Kelâmî, Lafzî, Lisânî, Güftî, Levhî, Makâlî, Nutkî, Meâlî, İlmî, Fennî, Fünûnî...

İntisap edilen bir şahsiyetten veya babanın meslek ve pâyesinden gelen mahlaslar da vardır: Askerî, Buhârî, Ca'ferî, Destârî, Gülşenî, Mekkî, Mîrî, Muîdî...

Bazı şairlerin mahlasları doğrudan doğruya meslekleriyle hüner sahibi oldukları iş ve sanatlardan alınmıştır: Kâtibî, Nişânî, Harîrî, Kandî, Muammâyî, Nakşî, Nigârî, Na'tî, Şehdî, Huffî...

Mûsikişinaslar: Nâyî, Makâmî, Negamî...

Tabipler: Şifâî, Tabîbî, Trâş̧î (cerrah).

Bazı mahlaslarda şair zevke düşkünlüğü ilân eder: Keyfî, Meşrebî, Rindî, Mezâkî, Ayşî, İşretî, Mestî, Nûşî, Sabûhî, Sâgarî... (Akün, 1994: 395).

Bu bağlamda Mahvî’nin de mahviyet, kendini hor görme, bir düşkünlük hâli ve talihsizlik ifade eden mahlaslardan birine talip olduğu görülmektedir.

Mahlaslar, şairin mizacını ve psikolojik konumunu ele veren önemli ipuçları olarak (İsen, 1997: 195) düşünüldüğünde de Mahvî’nin şiirlerinde talihsizliğini bildiren ifadelerin fazlalığ1, şiirlerinde genel olarak hâkim olan düşkünlük ve ümitsizlik hâli şairin, olumsuzluk çağrıştıran "Mahvî" mahlasını tercihinde psikolojik konumunun etkili olduğuna işaret etmektedir. Şiirlerinde yoğun bir biçimde karamsar ruh hâlini sergileyen şair, yansıtmak istediği bu olumsuz duyguları da "Mahvi" kelimesinin mahvolmak, harap olmak, yok olmak gibi anlamlarından da istifade ederek daha güçlü bir şekilde verebilmektedir. Mahvî aşağıdaki mahlas beyitlerinde talihsiz olduğundan, yine bahtının kara olduğundan yakınmakta ve arzularının gerçekleşmediğini ifade etmektir:

Mahvî felekden eylemedüm iltimâs-ı kâm

Bilmem niçün bu denlü beni b̂ิ-busû̀ ider $\quad(\mathrm{G} .46 / 5)^{3}$

(Mahvî, felekten arzumu yerine getirmesi için ricada bulunmadığım hâlde neden beni bu kadar huzursuz eder bilmem.)

Mahvî esîr-i dil-ber-i bî-mibr ider biæ̨i

Dil-düsmenî-i kevkeb-i babt-ı siyâhumuz，(G.54/5)

(Mahvî, kara bahtımızın yıldızının gönle düşmanlık etmesi bizi merhametsiz sevgilinin esiri eder.)

\footnotetext{
3 Örnek verilen beyitler için bk. Tok, 2020.
} 
TOK, Eda (2021). “Sebk-i Hindî Tesiri Bağlamında Mahvî Dîvânı'nda Karamsarlık”, Mavi Atlas, 9(1): 77-86

Berk-i nigebüñ 'âleme ger sâye salarsa

Mabvî gibi dünyâyz perîsân-nigeh eyler

(G. 37/5)

(Eğer bakışının şimşeği âlemi gölgelendirirse, dünyayı Mahvî gibi perişan bakışlı eder.)

Kerem-i baht-ı dûnile Mabvî

Olma gamdan halâs u çek. kederi (G.121/9)

(Mahvî, alçak talihin cömertliğiyle dertten kurtulma ve gamı çek.)

Bulur Mabvî nigâbunla tesellî

Meger mâni' ola babt-ı siyâhı $\quad(\mathrm{G} .118 / 7)$

(Kara bahtı engel olmazsa Mahvî bakışınla teselli bulur.)

Izdırap içinde olduğunu, ah çektiğini Hz. Yusufa yaptığ1 telmihle ifade eden şair, bu durumdan kurtulma kaygısı taşımamaktadır:

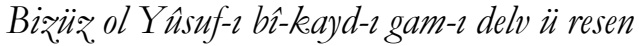

Dest-gî old kead-i zemzeme-i âh bize $\quad$ (G.116/4)

(Biz, o ip ve kova derdinden kurtulmuş olan Yusufuz. Bize ah nağmesinin boyu yardımcı oldu.)

Seng-i kazâya âyinemüz âsinâ iken

$H^{2}$ ân-ı belâya şevk ile mibmân olan biðür. (G.55/4)

(Aynamız kaza taşına tanıdıkken biz bela sofrasına şevkle misafir olanız.)

Mahvî, talihsiz olduğunu ifade etmek için "baht-1 siyâh" ifadesine (K. 1/12; G. 98/1, 118/7) şiirlerinde vurgu yapmış, aşağıdaki beyitte kara bahtının yıldızının gönül işlerini de olumsuz etkilediğini belirtmek için gönlüne düşmanlık ettiğini ifade etmiştir:

Mabvî esîr-i dil-ber-i bî-mibr ider biz̨i

Dil-düsmenî-i kevkeb-i babt-ı siyâhumuz. (G.54/5)

(Mahvî, kara bahtımızın yıldızının gönle düşmanlık etmesi bizi merhametsiz sevgilinin esiri eder.)

Şair başka bir beyitte ise kendisinin sert mizaçlı olmasına sebep olarak yine kara bahtını işaret etmektedir:

Mabvî esîr-i gamze-i sûubun degül midür

Babt-r siyâhr böyle seni tünd-bû ider

(Mahvî, sevgilinin yan bakışının esiri değil midir ki kara bahtı seni böyle huysuz eder.)

Şair bahtının kendisine sürekli gam çektirdiğini, dert hazinesi olduğunu ve sefanın ne olduğunu bilmediğini; gönül derdinin yüz parça olmuş olan sinesinden bile anlaşılabileceğini dile getirmektedir: 
Şâd olmag içün baht bizi gam çeker egler

Ümmîd-i tarabdan da yine bir. gilemendür. (G.53/4)

(Baht, mutlu olmak için bize gam çektirir. Biz yine sevinç ümidinden de şikâyetçiyiz.)

Esîr-i gamzę-i sûhbem rehâ nedür bilmem

Hąîne-i gam u derdem safâ nedür bilmem (G.82/1)

(Sevgilinin yan bakışının esiriyim, kurtuluş nedir bilmem. Dert ve keder hazinesiyim, zevk nedir bilmem.)

İtmedüm gayra şikâyet nice bir nâz yeter

Bilinür derd-i dilüm sîne-i sad-çâkümden (G.95/4)

(Yeter, daha ne kadar naz edeceksin? Başkasına şikâyet etmedim, gönül derdim yüz parça olmuş göğsümden anlaşıllır.)

Gönlü gam ve kederin yakıcilığından adeta ateşhaneye dönen ve sabahlara kadar ah edip gözyaşı döken şair, gözyaşındaki hâli bile ne kıvılcımda ne de kezzap denizinde görmediğini söyleyerek mübalağa yapmıştır:

Attesgede-i dil olah merhale-i gam

Zevk-i gama rubsatum virür kâfile-i gam (G.77/1)

(Ateşhane gibi olan gönülde dert konak olduğundan beri gam kafilesi dert zevki için bana izin verir.)

Girye-i dem-be-dem-i reşkile Mahvî dem-i subh

Dį̧erüm âh gibi tâze nihâl üstine gül $\quad$ (G.76/5)

(Mahvî, sürekli ağlayarak sabah vakti taze fidan üstüne gül gibi ah dizerim.)

Elmâs-ı sirişkë̈mde olan hâleti Mahvî

Ne şu'lede ne lücce-i tî̌r-âbda gördüm (G.78/7)

(Mahvî, elmas gibi olan gözyaşımın hâlini ne alevde ne kezzap ummanında gördüm.)

Şairin dîvânında yer alan iki gazelinin redifi “-1 gam (G.77), -yı gam (G. 79)” şeklindedir. Şiirlerinde genel itibarıla görülebilen dertli, gamlı ruh hâli bu gazellerde daha yoğun bir biçimde hissedilmektedir. Şair, aşağıdaki beyitte muradına erememiş gönlünün safa kokusundan zevk alsa o an tenindeki her kılın gama, derde hamile kalacağını söylemiş, mübalağa yaparak esasında karamsar ruh hâlini yansıtmıştır:

Bir neşve ala bû-yr safâdan dil-i nâ-kâm

Her mû-ỹ tenüm ol dem olur hâmile-i gam (G.77/4)

(Arzusuna ulaşamamış gönül mutluluk kokusundan bir zevk alsa o an tenimdeki her kıl derde hamile olur.)

Şair, o denli perişan bir hâldedir ki hâlini anlatmaya kalkışsa aklı deli eder; ayrılık derdini anlatmaya kalkışsa âlemi hasta eder: 
TOK, Eda (2021). “Sebk-i Hindî Tesiri Bağlamında Mahvî Dîvânı'nda Karamsarlık”, Mavi Atlas, 9(1): 77-86

'Aklı mecnûn eylerüm bâl-i perîşânum disem

'Âlemi bîmâr iderdüm derd-i bicrânum disem

(Perişan hâlimi söylesem aklı deli ederim. Ayr1lı derdimi söylesem âlemi hasta ederim.)

Şair, yine o denli acı çekmektedir ki ağlamaktan gözlerinden kanlı gözyaşı gelmekte öyle ki adeta ciğer parçasını kirpiğine süs etmektedir:

Çeşmüm yaşım aglamadan kan iderüm ben

Labt-ı cigerüm qinet-i müjgân iderüm ben (G. 103/1)

(Ben ağlamaktan gözyaşımı kan ederim. Ciğer parçamı kirpiğimin süsü yaparım.)

Şair, başka bir beytinde ise yanlışlıkla arzu kadehinden içecek olsa kıyamete dek gözlerinden kan geleceğini dile getirerek yine karamsar ruh hâlini yansıtmıştır:

Tâ haşre degin kan getürür dîdelerümden

Nûs itsem eger sehvle ben câm-ı temennâ

(Ĕger ben yanlışlıkla istek kadehinden içsem ta kıyamete kadar gözlerimden kan getirir.)

Şair ne kadar kan ağlasa da sevgilinin yaş dolu gözlerine merhamet etmeyeceğini düşünmektedir:

Eger kan aglasan Mahvî terabhum

İder mi dîde-i giryâna ol șîh $\quad$ (G.17/5)

(Mahvî, eğer kan ağlasan o güzel sevgili ağlayan, yaşlı göze merhamet eder mi?)

Bir insanı diğerlerinden ayıran özelliklerden biri ümidinin olmasıdır. Ümit ve hayal birbiriyle bağlantılı olup özellikle kişinin hayallerinin yıkılmasıyla ümitlerinin de zayıfladığı, azaldığı veya yok olduğu görülür. Sanatçılar da hayalleri ve ümitleriyle diğerlerinden farklı bir yere sahiptir. Sanatçılar, son derece hassas ve kırıllgan olduklarından eserlerinde ümit-ümitsizlik çatışmasını çokça yaşarlar (Ulucan, 2019: 83-84). Mahvî'nin șiirlerinde gerek sanatçı hassasiyetinden gerekse Sebk-i Hindî’nin temalarından biri olması bakımından ümitsizlik de dikkat çeken karamsar ruh hâllerinden biridir. Şair zaman zaman ümitsizlik içerisinde olduğunu dile getirmekte olup aşağıdaki beyitte ümitsizliğin istilasıyla güçsüz düştüğünü söylemiştir:

Şöyle bî-tâb itdi istîlâ-yn nevmîdî beni

Pâyuma nûr-ı nigâbum mevce-i gird-âb olur (G. 30/3

(Beni ümitsizlik istilası o kadar güçsüz etti ki bakışımın feri dahi ayağıma/takatime girdap dalgasi olur.)

Bir başka beyitte ise tenindeki her bir kılın kandil olsa yine de ümit evinin bir an bile aydınlanmayacağını söyleyerek aşırı ümitsiz olduğunu ifade etmektedir:

Hâne-i ümmîdüm olmaz bir nefes rûssen benüm

Olsa ber mû ger tenümde bir çerâg-ı ârzûu (G.104/2)

(Tenimdeki her kil bir arzu kandili olsa benim ümit evim bir an aydınlanmaz.)

Mahvî dertsiz, gamsız, ızdırapsız rahat olamayacağını aşağıdaki beyitte dile getirmiştir: 


\section{Mabvî gibi ârâm idemem olmasa derdüm \\ Destüm ideli çâk-ı girîbânile ülfet (G.12/6)}

(Elim yaka yırtmakla dostluk ettiğinden beri derdim olmasa Mahvî gibi rahat edemem.)

\section{Sonuç}

XVII. yüzyıl şairlerinden Mahvî Ahmed Çelebi'nin şiirleri değerlendirildiğinde Sebk-i Hindî'den oldukça etkilendiği görülmektedir. Mahvî'nin şiirlerinde özellikle soyut ve somut kelimelerin birleştirilmesiyle elde edilen, üç-dört unsurdan oluşan uzun ve girift tamlamalara sıkça tesadüf edilmektedir. Mahvî̀nin șiirlerinde bu üslubun belirgin özelliklerinden biri olan yeni hayaller bulma, hayallere derinlik kazandırma çabası da zaman zaman görülmektedir. Şairin şïrlerinde aşırıya kaçan mübalağa örneklerinin çokça bulunması yine şiirlerinin dikkat çeken özellikleri arasındadır.

Mahvî’nin şiirlerinde gam, elem, ızdırap, karamsarlık konularının yoğun bir biçimde işlendiği görülmektedir. Izdırap, Hint üslubu şairlerinin belirgin özelliklerinden olup çağdaşı olan ve bu üslubun temsilcileri arasında kabul edilen Nâilî ve Şehrî gibi şairlerin de şiirlerinde işlediği bir konudur. Nâilî ve Şehrî’nin şiirlerinde 1zdırap temasını yoğun işlemelerinde Hind üslubunun özelliği olmasının yanı sıra hayatlarında çok acı çekmiş olmaları da tesirli olmuştur. Mahvî de şiirlerinde gam, derd, ah, dâg, nâle, mihnet, girye, nâ-ümîdî, nâ-murâd, nâ-kâm, baht-ı dûn, bî-buž̂ur, bî-çâre, baht-ı sìyâh, kan ağlamak gibi olumsuzluk ifadelerini sıklıkla kullanarak ümitsiz ve karamsar bir ruh hâlini ön planda tutmaktadır. Şairin şiirlerinde talihsizliğini bildiren ifadelerin fazlalığı, şiirlerinde genel olarak hâkim olan düşkünlük ve ümitsizlik hâli şairin, olumsuzluk çağrıştıran "Mahvî" mahlasını tercihinde de psikolojik konumunun etkili olduğuna işaret etmektedir. Ancak şairin hayatı hakkındaki bilgiler oldukça sınırlı olduğu için şairin şiirlerine yansıttı̆̆ bu karamsar, ümitsiz ruh hâlinde yaşamının tesirinin hangi düzeyde etkili olduğunu söylemek güçtür. Şairin şiirlerine yansiyan bu karamsar ruh hâline sebep olanın yaşadığı hayatın şartları olup olmadığı bilinmemekle beraber bu temayı yoğun bir biçimde işlemesinin benimsediği Sebk-i Hindı̂’den kaynaklandığı kuvvetle muhtemeldir.

\section{Kaynakça}

ABDULKADIROĞLU, Abdulkerim (1985). İsmail Beliğ, Nubbetü'l-âsâr Li-Zeyli Zübdeti'lEş'âr, Ankara: Gazi Üniversitesi Yayını.

AKÜN, Ömer Faruk (1994). "Divan Edebiyatı", TDV İslam Ansiklopedisi, Cilt 9, ss. 389427, İstanbul: Türkiye Diyanet Vakfi Yayınları.

AYPAY, İrfan (1998). "Mahvî, Hayatı, Eserleri, Edebî Kişiliği ve Divançesi”, Kütabyalı Şairler Sempozyumu-I, ss. 226-253, Kütahya.

BABACAN, İsrafil (2012). Klâsik Türk Şïrinin Son Babar, Sebk-i Hindî (Hint Üslûbu), Ankara: Akçă̆ Yayınları.

BİLKAN, Ali Fuat (2009). "Sebk-i Hindî”, TDV İslam Ansiklopedisi, Cilt 36, ss. 253-255, İstanbul: Türkiye Diyanet Vakf1 Yayınları.

ÇAPAN, Pervin (2005). Mustafa Safayi Efendi, Tę̧kire-i Safâyî (Nubbetü'l-âsâr Min Fevâ'idi'lEş'âr), Ankara: AKM Yayınları.

DEMİREL, Şener (2006). “17. Yüzyll Sebk-i Hindî Şairlerinden Nâilî ve Fehîm’in Şiirlerinde Somutlaştırma veya Alış1lmamış Bağdaştırmalar”, Eski Türk Edebiyatı Çalışmalar 1-Sözde ve Anlamda Farkhlasma, Sebk-i Hindî, 29 Nisan 2005 Bildiriler, haz. Hatice Aynur, Müjgan Çakır ve Hanife Koncu, ss. 34-88, İstanbul: Turkuaz Yayınları.

DEMIREL, Şener (2017). "Şehrî Dîvânı", Erişim Tarihi: 10.10.2020, (https://ekitap.ktb.gov.tr/Eklenti/56340,sehri-divanipdf.pdf?0).

İPEKTEN, Halûk (2016). Nâili Hayatı-Sanatı-Eserleri-Bąı Sïrlerinin Açıklaması, Ankara: Akçă̆ Yayınları. 
TOK, Eda (2021). “Sebk-i Hindî Tesiri Bağlamında Mahvî Dîvânı'nda Karamsarlık”, Mavi Atlas, 9(1): 77-86

İSEN, Mustafa (1997). "Divan Edebiyatında Mahlasdaş Şairler”, Ötelerden Bir Ses, Divan Edebiyatı ve Balkeanlarda Türk Edebiyatı Üzerine Makaleler, ss. 195-208, Ankara: Akçă̆ Yayınları.

MUM, Cafer (2006). "Sebk-i Hindi”, Türk Edebiyatı Taribi, Cilt 2, ss. 369-392, İstanbul: Kültür ve Turizm Bakanlı̆̆1 Yayınları.

MUM, Cafer (2011). Divan Şïrinde Bercesteli Beyitler, Malatya: Mengüceli Yayınları.

ÖZCAN, Abdülkadir (1989). Şeyhî Mehmed Efendi, Vakâyi'ül-Fuzalâ, Cilt 1, İstanbul: Çağr1 Yayinları.

TOK, Eda (2020). Kütabyalı Mahvî Dîvân, İstanbul: Kesit Yayınları.

TOKER, Halil (1996). "Sebk-i Hindî (Hind Üslubu)", İlmî Araştırmalar: Dil, Edebiyat, Tarih Incelemeleri, 2, ss. 141-150. Yayınları.

ULUCAN, Mehmet (2019). Geleneksel ve Özgün Taraflaryla Fuzûlî ve Şïri, İstanbul: Kitabevi 